\title{
Nitroglycerin as Adjuvant to Two Different Doses of Lidocaine During IVRA for Hand Surgery
}

\author{
Tamer MA Ewieda* \\ Department of Anesthesia, Al-Azhar University, Egypt
}

Submission: August 31, 2019; Published: October 18, 2019

*Corresponding author: Tamer MA Ewieda, Department of Anesthesia, Faculty of Medicine, Al-Azhar University, Egypt

\begin{abstract}
Objectives: To evaluate anesthetic and operative outcome of using nitroglycerin (NTG) as an adjunct to intravenous regional anesthesia (IVRA).

Patients and methods: 165 patients assigned for elective hand and forearm surgery were divided into three equal groups: Control group received lidocaine $2 \%(3 \mathrm{mg} / \mathrm{kg}$ ) and Study groups received NTG $200 \mu \mathrm{g}$ with full (Group I) or half-dose LA (Group II) diluted with saline for total volume of $40 \mathrm{ml}$. Tourniquet was deflated at $30 \mathrm{~min}$ in study groups, irrespective of surgery duration and at end of surgery in control group. Study outcomes include onset and recovery times of sensory and motor blocks, need for intraoperative (IO) and postoperative (PO) analgesia, PO pain scores and duration till hospital discharge.
\end{abstract}

Results: NTG favorably improved anesthetic procedure with significantly shorter onset-time of blocks and longer onset-time of tourniquet pain. NTG/half-dose LA combination also did favorably than LA alone, but less than NTG/full-dose LA. Duration till block full recovery was significantly longer in NTG patients than controls with lower pain scores and analgesia consumption. Duration of PO analgesia was nonsignificantly longer in group II than control group but was significantly different in favor of group I than other groups. Twenty-seven patients received no PO analgesia with significant difference in favor of NTG than control groups. No patient developed drug-related complications or hemodynamic alterations. Duration of hospital stay was significantly shorter in NTG patients than controls.

Conclusion: Use of IVRA for hand and distal forearm surgery is efficient and safe modality for IO anesthesia and PO analgesia. Addition of NTG to LA improved anesthetic outcome and allowed shortening of initiation of surgery, less IO and PO analgesic consumption. Reduction of LA dose did not compromise the reported improved anesthetic outcome. Rapid tourniquet release did not alter patients hemodynamic.

Keywords: IVRA; Nitroglycerin; Tourniquet release; Rescue analgesia; Outcome

\section{Introduction}

Most surgeries at the wrist and forearm are performed using a tourniquet to minimize blood loss [1] and are carried upon under general anesthesia [2], local infiltration [3], brachial plexus blocks [2] or intravenous regional anesthesia (IVRA) [4]. IVRA is an effective method of providing anesthesia for extremity surgery, with published success rates ranging from $94 \%$ to $98 \%$ [5]. Despite of the settled efficacy of IVRA, it may be associated with serious complications related to local anesthetic (LA) toxicity that may be occurred secondary to LA leak [6], accidental tourniquet release or rapid tourniquet deflation [7]. However, exsanguinations of the limb prior to tourniquet inflation decrease the amount of blood distal to the cuff and this reduces blood in the surgical field and may limit peak plasma levels of LA when the cuff is deflated [8]. Nitroglycerin (NTG) has a rapid onset of action and short half-life with a clear dose-response curve on both global hemodynamics and peripheral circulation [9]. Nitrates predominantly induce vasodilation in large capacitance blood vessels and impair platelet aggregation [10]. Nitric oxide (NO) is a biological mediator that blocks the nociceptive stimulus in the peripheral nervous system through an increase in postsynaptic neuron GMPc [11]. NTG is metabolized in the cell giving rise to short lived intermediates, which liberate NO that activates the guanylate cyclase enzyme, increasing the GMPc [12]. Time of tourniquet application was determined according to patients' tolerance to ischemic pain [13] and tourniquet must be released gradually or using intermittent episodes of inflation and deflation to allow gradual wash of LA so as to minimize the possible LA-related side effects [14].

\section{Hypothesis}

This study hypothesized that NTG as an adjunct to IVRA, owing to its vasodilator effect allow rapid and perfect tissue perfusion of LA, thus may improve performance of IVRA and allow tourniquet release without time limit, thus improving anesthetic outcome and may allow reduction of LA dose without compromising the outcome. 


\section{Setting}

Doha Clinic Hospital, Qatar

\section{Design}

Prospective study

\section{Patients and Methods}

The study was conducted at Department of Anesthesia at Doha Clinic Hospital, Qatar since Nov 2016 till Nov 2017. The study protocol was approved by the Local Ethical Committee and only patients who signed written fully informed consents were enrolled in the study. All ASA I and II patients who were assigned for elective hand, wrist or distal forearm surgery requiring operative time range of $45-90 \mathrm{~min}$ were included in the study. Patients needed urgent or emergency surgery, had extensive hand trauma, cardiac, renal or hepatic diseases, past history of habitual hypotension or allergy to study drugs or intolerant to tourniquet pain were excluded from the study. All patients underwent clinical examination to assure inclusion and exclusion criteria and to determine baseline demographic and clinical data. All patents were premedicated with $0.1 \mathrm{mg} / \mathrm{kg}$ midazolam and atropine $0.01 \mathrm{mg} / \mathrm{kg}$; administered intramuscularly 45 minutes prior to surgery, for sedation and relief of apprehension; but no analgesics or opiates were given. Two intravenous cannulas were applied, one in the operative extremity for administration of the study solution and the other in the contra-lateral extremity for intravenous injection of other medications or fluids when indicated. After application of routine monitors, a double pneumatic tourniquet was positioned on the upper arm of the operative extremity that was exsanguinated from distal to proximal by elevation for $2 \mathrm{~min}$ followed by application of Esmarch bandage to induce circulatory isolation of arm that was confirmed by inspection of the color of the limb, absence of radial pulse and loss of pulse oximetry tracing. Then, the proximal tourniquet was inflated up to $100 \mathrm{mmHg}$ above baseline systolic blood pressure, but not exceeding $250 \mathrm{mmHg}$, and Esmarch bandage was removed [15].

Patients were randomly, using sealed envelopes prepared by blinded assistant and chosen by patients themselves, divided into three equal groups: Control group included patients received preservative free lidocaine $2 \%$ in a dose of $3 \mathrm{mg} / \mathrm{kg}$ and calculated amount was diluted with saline up to a total volume of $40 \mathrm{ml}$ without additives. Study group I targets to evaluate the additive effect of NTG and included patients received preservative free lidocaine $2 \%$ in a dose of $3 \mathrm{mg} / \mathrm{kg}$ and calculated amount was mixed with $200 \mu \mathrm{g}$ of nitroglycerin and was diluted with saline up to a total volume of $40 \mathrm{ml}$. Study group II targets to outcome of IVRA using $200 \mu \mathrm{g}$ of nitroglycerin and half-dose of LA used for other groups (lidocaine $2 \%$ in a dose of $1.5 \mathrm{mg} / \mathrm{kg}$ ) diluted with saline up to a total volume of $40 \mathrm{ml}$. Anesthetic solutions were prepared by an assistant who was blinded about study hypothesis and patients' randomization. Solution which was assigned for each group was injected intravenously through the cannula applied in the operative extremity through 90 seconds. On sensation of discomfort at the proximal tourniquet site, it was deflated after inflation of the distal tourniquet to the same pressure. In all groups, the tourniquet was not kept inflated for $>2 \mathrm{~h}$, but was deflated at $30 \mathrm{~min}$ in study groups, irrespective of duration of surgery, while in control group the tourniquet was deflated on completion of surgery. For all patients two-stage tourniquet deflation was followed where tourniquet was deflated for 10 seconds and re-inflated for 1 minute before the final release so as to allow for a more gradual "washout" of local anesthetic [16].

\section{Intraoperative assessment}

a) Cutaneous sensation was checked using pin prick method every minute all over the front and dorsum of the hand and forearm and time elapsed since drug injection till sensory block was achieved in all dermatomes was determined as duration till onset of sensory block.

b) Motor block was defined as loss of ability to flex and extend fingers and wrist; time till achieving motor block since drug injection was determined as duration till onset of motor block.

c) Intraoperative analgesia was evaluated by Visual Analogue Scale (VAS) of 0-10 every 10 minutes $(0=$ "no pain" and $10=$ "worst pain imaginable"). Time of onset of tourniquet pain was defined as time lapsed between complete sensory block till patient feels pain scored at $>3$ on the VAS scale. Intravenous fentanyl injection was given in a dose $1 \mu \mathrm{g} / \mathrm{kg}$ to patients who had tourniquet pain of $>3$. The numbers and total dose of IO fentanyl injections was also recorded.

d) Mean arterial pressure (MAP) and heart rate (HR) were non-invasively monitored throughout duration of surgery.

e) Operative time and time till release of tourniquet were also recorded.

\section{Postoperative assessment}

a) Durations till complete sensory recovery and motor recovery were defined as the time elapsed from release of tourniquet to full sensory recovery and return of full motor activity, respectively.

b) Duration of PO analgesia was defined as time till first analgesic request of rescue analgesia. Rescue analgesia was given on VAS $>4$ in the form of intramuscular injection of diclofenac sodium $(75 \mathrm{mg} / \mathrm{ml} ; 3 \mathrm{ml}$ ampoule).

c) MAP, HR and VAS pain score were recorded hourly for 4 hours.

d) Frequency of LA or NTG-related complications, as sensitivity reactions, altered hemodynamic parameters was recorded. 
e) All patients were managed as one-day surgical case and duration since complete sensory and motor recovery till hospital-discharge was recorded as time of PO hospital stay.

\section{Statistical analysis}

Sample size was calculated using the standard nomogram proposed by Kraemer \& Thiemann [17] and a sample size of $\geq 40$ patients per group was determined to be sufficient to detect a difference at the $5 \%$ significance level and give the trial $80 \%$ power Results
[18]. Sample size and power were re-calculated and assured using Power and Sample Size Calculation Software program provided by Department of Biostatistics, Vanderbilt University. Obtained data were presented as mean $\pm \mathrm{SD}$, ranges, numbers and ratios. Results were analyzed using Student t-test, ANOVA test and Chi-square test (X2 test). Statistical analysis was conducted using the IBM SPSS (Version 23, 2015) for Windows statistical package. P value $<0.05$ was considered statistically significant.

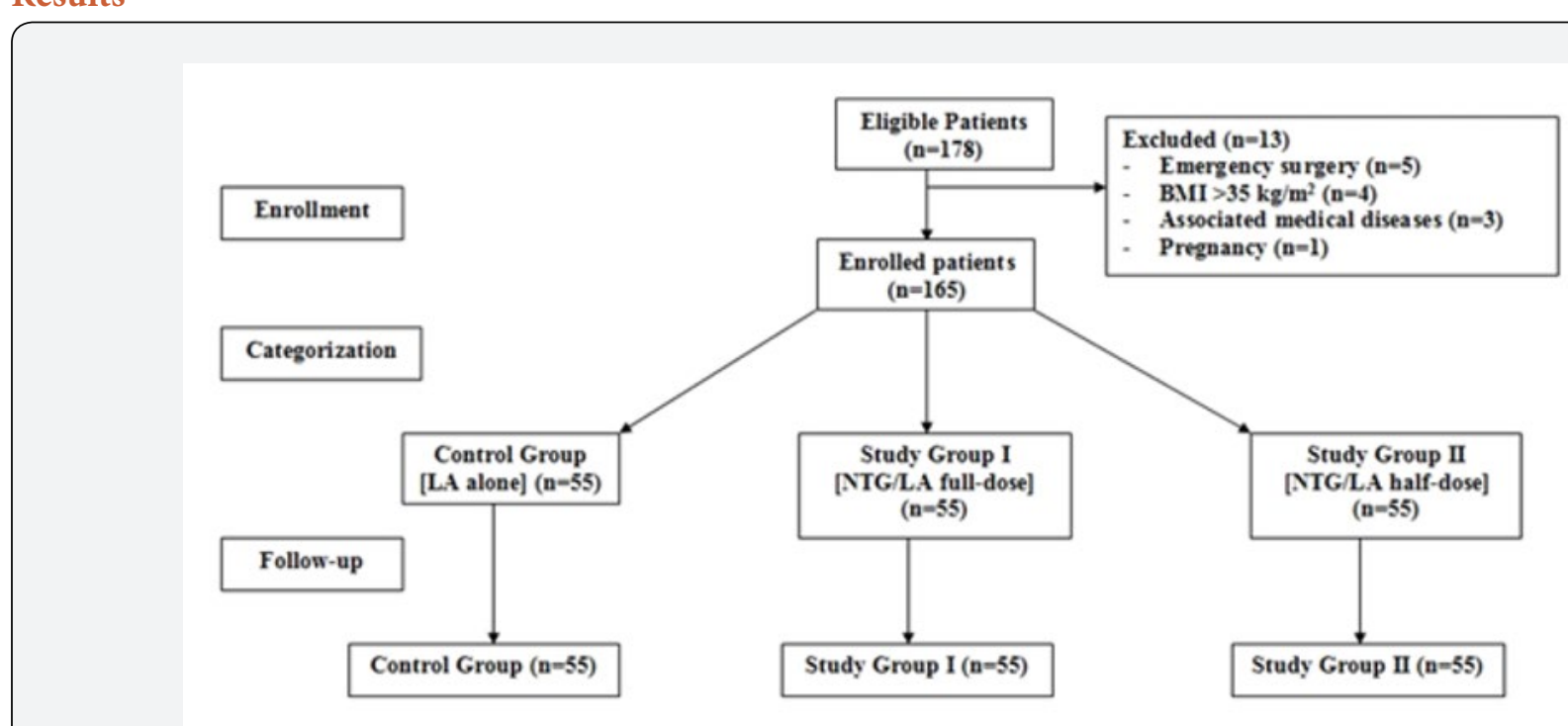

Figure 1: Flow chart of the study.

Table 1: Patients' characteristics.

\begin{tabular}{|c|c|c|c|c|c|}
\hline \multicolumn{2}{|c|}{ Parameter } & $\begin{array}{l}\text { Control Group (lidocaine 3mg/ } \\
\text { kg) }\end{array}$ & $\begin{array}{c}\text { Study I } \\
\text { Group (lidocaine 3mg/ } \\
\mathrm{kg}+ \\
200 \mu \mathrm{g} \mathrm{ntg})\end{array}$ & $\begin{array}{c}\text { Study II } \\
\text { Group (lidocaine } \\
1.5 \mathrm{mg} / \mathrm{kg}+200 \mu \mathrm{g} \\
\mathrm{ntg})\end{array}$ & $P$ value \\
\hline \multicolumn{2}{|c|}{ Age (years) } & $36.9 \pm 8$ & $35.9 \pm 8.9$ & $36.2 \pm 8.2$ & 0.375 \\
\hline \multicolumn{2}{|c|}{ Sex, M:F } & $40: 15$ & $35: 20$ & $37: 18$ & 0.453 \\
\hline \multirow{3}{*}{ BMI data } & Weight (kg) & $81 \pm 11.3$ & $82.4 \pm 13.6$ & $81.3 \pm 11.4$ & 0.297 \\
\hline & Height $(\mathrm{cm})$ & $169.2 \pm 3.9$ & $169.6 \pm 3.4$ & $169.3 \pm 3.9$ & 0.731 \\
\hline & BMI $\left(\mathrm{kg} / \mathrm{m}^{2}\right)$ & $28.3 \pm 3.8$ & $28.6 \pm 4.5$ & $28.3 \pm 3.8$ & 0.504 \\
\hline \multicolumn{2}{|c|}{ ASA grade; I: II } & $43: 12$ & $44: 11$ & $47: 8$ & 0.597 \\
\hline \multirow{5}{*}{$\begin{array}{l}\text { Operative proce- } \\
\text { dure }\end{array}$} & Carpal Tunnel release & $14(25.5 \%)$ & $16(29.1 \%)$ & $13(23.6 \%)$ & \multirow{5}{*}{0.619} \\
\hline & Carpal bone fixation & $12(21.8 \%)$ & $10(18.2 \%)$ & $11(20 \%)$ & \\
\hline & $\begin{array}{l}\text { Contracture release \& } \\
\text { tendon advancement }\end{array}$ & $7(12.7 \%)$ & $9(16.4 \%)$ & $9(16.4 \%)$ & \\
\hline & Tenolysis & $16(29.1 \%)$ & $13(23.6 \%)$ & $17(30.9 \%)$ & \\
\hline & Plastic & $6(10.9 \%)$ & $7(12.7 \%)$ & $5(9.1 \%)$ & \\
\hline
\end{tabular}

Data are presented as mean \pm SD and numbers; percentages are in parenthesis.

One hundred and seventy-eight patients were eligible for evaluation, 13 patients were excluded, and 165 patients were included (Figure 1). There was non-significant $(\mathrm{p}<0.05)$ difference between patients of the study groups as regards inclusion data as shown in (Table 1). Mixing LA solution with NTG favorably improved the anesthetic procedure where duration till onset of sensory and motor blocks were significantly shorter with significantly longer time till onset of tourniquet pain that required fentanyl injection in patients of study groups than patients of control group (Table 2). Also, combination of NTG and half-dose LA did favorably in comparison to LA alone but showed significantly longer duration till onset of sensory block and significantly 
shorter time till onset of tourniquet pain compared to patients received NTG and full-dose LA (Table 2). However, the difference between patients of study groups I and II as regards onset of motor block and the total consumed dose of fentanyl was nonsignificant, despite being in favor of full dose. All surgeries were conducted uneventfully with no hemodynamic alterations and duration of surgery showed non-significant difference between the three groups (Table 2). Duration till sensory and motor full recovery was significantly longer in all patients received NTG than patients received LA alone with significantly longer durations in patients of study group I than those of study group II (Table 3). At 1-hr PO, mean PO pain VAS scores were significantly lower in patient of study groups compared to control patients with significant difference between both study groups in favor of study group I (Table 3). Thereafter, the inter-group difference was nonsignificant. Duration of PO analgesia was significantly longer in patient of study group II compared to patients of other groups with non-significantly longer duration of $\mathrm{PO}$ analgesia documented by patients of study group II compared to control patients (Table 3). At time of discharge, 27 patients were discharged without requesting rescue analgesia; 13 and 10 in study groups I and II, and only four in control group with significantly higher frequency of patients requested rescue analgesia in control versus patients of study groups I ( $\mathrm{p}=0.018)$ and II $(\mathrm{p}=0.0482)$, while the difference was non-significant $(\mathrm{p}=0.086)$ between patients of study groups I and II, but in favor of group II (Table 3). No patient developed LA or NTG-related complications or hemodynamic alterations. All patients were managed as one-day case, but patients of study groups were discharged after significantly shorter duration than control patients with significant difference between patients of study groups in favor of study group I (Table 3).

Table 2: Intraoperative data.

\begin{tabular}{|c|c|c|c|c|}
\hline Parameter & & $\begin{array}{l}\text { Control Group (lido- } \\
\text { caine } 3 \mathrm{mg} / \mathrm{kg} \text { ) }\end{array}$ & $\begin{array}{l}\text { Study I Group (lidocaine } 3 \mathrm{mg} / \mathrm{kg}+ \\
200 \mu \mathrm{g} \mathrm{ntg} \text { ) }\end{array}$ & $\begin{array}{l}\text { Study II Group (lidocaine } 1.5 \mathrm{mg} / \\
\mathrm{kg}+200 \mu \mathrm{g} \mathrm{ntg})\end{array}$ \\
\hline \multirow{3}{*}{$\begin{array}{l}\text { Duration till onset of } \\
\text { sensory block (min) }\end{array}$} & Mean $( \pm \mathrm{SD})$ & $4.71 \pm 1.4$ & $3.5 \pm 0.9^{*}$ & $3.9 \pm 1.2^{*}$ \\
\hline & P1 & & $<0.001$ & 0.001 \\
\hline & $\mathrm{P} 2$ & & & 0.008 \\
\hline \multirow{3}{*}{$\begin{array}{l}\text { Duration till motor block } \\
\qquad(\mathrm{min})\end{array}$} & Mean $( \pm \mathrm{SD})$ & $7 \pm 1.9$ & $5.3 \pm 1.2^{*}$ & $5.8 \pm 1.6^{*}$ \\
\hline & $\mathrm{P} 1$ & & $<0.001$ & 0.004 \\
\hline & $\mathrm{P} 2$ & & & 0.093 \\
\hline \multirow{3}{*}{$\begin{array}{l}\text { Time of onset of tourni- } \\
\text { quet pain (min) }\end{array}$} & Mean $( \pm \mathrm{SD})$ & $21.4 \pm 5.1$ & $29.1 \pm 1.3^{*}$ & $24.9 \pm 4.1^{*}$ \\
\hline & P1 & & $<0.001$ & 0.002 \\
\hline & $\mathrm{P} 2$ & & & 0.001 \\
\hline \multirow{3}{*}{$\begin{array}{l}\text { Intraoperative fentanyl } \\
\qquad(\mu \mathrm{g})\end{array}$} & Mean $( \pm \mathrm{SD})$ & $91.7 \pm 84.4$ & $50.6 \pm 60.3^{*}$ & $61.4 \pm 60.2^{*}$ \\
\hline & P1 & & 0.005 & 0.023 \\
\hline & $\mathrm{P} 2$ & & & 0.169 \\
\hline \multirow{3}{*}{ Operative time (min) } & Mean $( \pm \mathrm{SD})$ & $52.6 \pm 10$ & $54 \pm 10.5$ & $53 \pm 11.6$ \\
\hline & P1 & & 0.469 & 0.870 \\
\hline & P2 & & & 0.379 \\
\hline
\end{tabular}

Data are presented as mean \pm SD and numbers; percentages are in parenthesis;

$\mathrm{P} 1$ indicates significance of difference versus control group;

P2 indicates significance of difference versus Study I group;

*: indicates significant difference

Table 3: Assessment of PO analgesia.

\begin{tabular}{|c|c|c|c|c|}
\hline Parameter & & $\begin{array}{c}\text { Control group (lidocaine } \\
3 \mathrm{mg} / \mathrm{kg} \text { ) }\end{array}$ & $\begin{array}{c}\text { Study I } \\
\text { group (lidocaine } 3 \mathrm{mg} / \mathrm{kg}+ \\
200 \mu \mathrm{g} \text { NTG) }\end{array}$ & $\begin{array}{c}\text { Study II } \\
\text { group (lidocaine } 1.5 \mathrm{mg} / \mathrm{kg}+ \\
200 \mu \mathrm{g} \text { NTG) }\end{array}$ \\
\hline \multirow{3}{*}{$\begin{array}{l}\text { Duration till sensory block } \\
\text { recovery (min) } \\
\text { P1 } \\
\text { P2 }\end{array}$} & $\begin{array}{l}\text { Mean } \\
( \pm \text { SD })\end{array}$ & $4.1 \pm 1.8$ & $6 \pm 1.6^{*}$ & $5.2 \pm 1.4^{*}$ \\
\hline & & $<0.001$ & 0.002 & \\
\hline & & & 0.001 & \\
\hline \multirow{3}{*}{$\begin{array}{l}\text { Duration till motor block reco- } \\
\text { very (min) } \\
\text { P1 } \\
\text { P2 }\end{array}$} & $\begin{array}{l}\text { Mean } \\
( \pm \text { SD) }\end{array}$ & $5 \pm 2$ & $6.7 \pm 1.8^{*}$ & $5.88 \pm 1.3^{*}$ \\
\hline & & $<0.001$ & 0.012 & \\
\hline & & & 0.021 & \\
\hline
\end{tabular}


Journal of Anesthesia \& Intensive Care Medicine

\begin{tabular}{|c|c|c|c|c|c|}
\hline \multirow{12}{*}{ PO pain VAS score } & \multirow{3}{*}{$1-\mathrm{hr}$} & $\begin{array}{l}\text { Mean } \\
( \pm \text { SD })\end{array}$ & $2.4 \pm 0.6$ & $1.8 \pm 0.9^{*}$ & $2.1 \pm 0.8^{*}$ \\
\hline & & P1 & & 0.001 & 0.006 \\
\hline & & P2 & & & 0.005 \\
\hline & \multirow{3}{*}{$2-\mathrm{hr}$} & $\begin{array}{l}\text { Mean } \\
( \pm \text { SD })\end{array}$ & $1.9 \pm 1.2$ & $1.8 \pm 0.9$ & $1.85 \pm 1.1$ \\
\hline & & P1 & & 0.735 & 0.797 \\
\hline & & P2 & & & 0.912 \\
\hline & \multirow{3}{*}{$3-\mathrm{hr}$} & $\begin{array}{l}\text { Mean } \\
( \pm \text { SD })\end{array}$ & $1.4 \pm 1.2$ & $1.7 \pm 1.1$ & $1.3 \pm 1.3$ \\
\hline & & $\mathrm{P} 1$ & & 0.110 & 0.754 \\
\hline & & P2 & & & 0.066 \\
\hline & \multirow{3}{*}{$4-\mathrm{hr}$} & $\begin{array}{l}\text { Mean } \\
( \pm \text { SD })\end{array}$ & $1.3 \pm 1.1$ & $1.4 \pm 1$ & $1.15 \pm 0.9$ \\
\hline & & P1 & & 0.654 & 0.495 \\
\hline & & P2 & & & 0.261 \\
\hline \multirow{4}{*}{\multicolumn{2}{|c|}{$\begin{array}{l}\text { Frequency of requests } \\
\text { No } \\
\text { P1 } \\
\text { P2 }\end{array}$}} & Yes & $51(92.7 \%)$ & $42(76.4 \%)$ & $45(82.8 \%)$ \\
\hline & & $4(7.3 \%)$ & 13 (23.6\%)* & $10(18.2 \%)$ & \\
\hline & & & 0.018 & 0.086 & \\
\hline & & & & 0.0482 & \\
\hline \multirow{3}{*}{\multicolumn{2}{|c|}{$\begin{array}{l}\text { Duration of PO analgesia (min) } \\
\text { P1 } \\
\text { P2 }\end{array}$}} & $\begin{array}{l}\text { Mean } \\
( \pm \text { SD })\end{array}$ & $50.6 \pm 60.3$ & $91.7 \pm 84.4^{*}$ & $61.4 \pm 60.2^{*}$ \\
\hline & & & 0.005 & 0.169 & \\
\hline & & & & 0.023 & \\
\hline \multirow{3}{*}{\multicolumn{2}{|c|}{$\begin{array}{l}\text { Duration of PO hospital stay } \\
\text { (min) } \\
\text { P1 } \\
\text { P2 }\end{array}$}} & $\begin{array}{l}\text { Mean } \\
( \pm S D)\end{array}$ & $269 \pm 19.7$ & $244 \pm 6.5^{*}$ & $251 \pm 13.3^{*}$ \\
\hline & & & 0.001 & 0.001 & \\
\hline & & & & 0.029 & \\
\hline
\end{tabular}

Data are presented as mean \pm SD and numbers; percentages are in parenthesis;

$\mathrm{P} 1$ indicates significance of difference versus control group;

P2 indicates significance of difference versus Study I group;

*: indicates significant difference

\section{Discussion}

Nitroglycerin (NTG) as an adjuvant to local anesthetic (LA) during IVRA for elective hand and distal forearm surgeries favorably and significantly improved anesthetic outcome; using either lidocaine 3 or $1.5 \mathrm{mg} / \mathrm{Kg}$ in $40 \mathrm{ml}$ saline, manifested as significantly shorter block initiation time, longer block duration, lower tourniquet pain scores and IO fentanyl consumption. Additionally, NTG/LA combination allowed better PO course manifested as significantly lower scores at 1-hr PO and nonsignificantly lower scores till end thereafter and lower number of requests of rescue analgesia thus significantly shortened time of PO hospital stay. The obtained results go in hand with Asadi \& Mehri [19] and Cakmak et al. [20] who in similar comparative studies, found the onset time of sensory and motor blockades was shorter and mean recovery time of sensory blockade was longer with significantly lower opioid consumption in patients received NTG/LA combination versus LA only. Thereafter, Bansal et al. [21] compared the efficacy of magnesium sulphate and NTG as adjuncts during IVRA and reported shorter sensory and motor block onset times and significantly prolonged recovery times with both drugs compared to lidocaine alone and concluded that addition of either of magnesium sulphate and NTG to lidocaine for IVRA lead to early onset of sensory block and prolonged PO analgesia. The significantly shorter onset and delayed block recovery in patients received NTG/LA versus patients received LA alone could be attributed to a direct potent vasodilatory effect that promotes rapid in situ diffusion of LA to nerves, or to direct stimulation of peripheral nerve fibers by an action similar to that of locally applied acetylcholine, or to inherent anti-nociceptive effect of NTG. In support of the anti-nociceptive effect of NTG, the reported lower IO and PO pain VAS scores and the lesser consumption of rescue analgesia by patients who received half-dose of LA compared to patients received LA only. Moreover, the current study provided an evidence for dose dependent NTG analgesic effect. Such antinociceptive effect of NTG could be attributed to the facts that NTG is metabolized in the cell to nitric oxide [22], which increases the intracellular concentration of cyclic guanosine monophosphate, a pain modulator acting both centrally and peripherally [23] through sensitization of wide-dynamic-range neurons located in the superficial and deep dorsal horns and through attenuation of 
inhibition of these neurons caused by stimulated periaqueductal gray secondary to transmission of painful stimuli [24]. As another possible explanation for the favorable outcome of IVRA using NTG/LA, is the synergistic interaction between $\mu$-opioid receptors and NO [25] where NO has direct modulatory effects on N-methylD-aspartate receptors [26] and gamma-aminobutyric acid-A receptors [27].

The release of tourniquet at $30 \mathrm{~min}$ IO, irrespective of operative duration in patients of study groups passed smoothly without significant hemodynamic effects secondary to the use of LA with/without NTG. These findings indicated the safety of IVRA using LA alone or in combination with NTG. In support of the safety of NTG, Honarmand et al. [28] compared the effect and safety of IVRA using NTG/LA combination in three doses; 200, 300 and $400 \mu \mathrm{g}$ and detected superior effect of IVRA using NTG/ LA combination versus LA alone and no deleterious hemodynamic effects even with the high NTG dose which is double of the dose used in the present study. Thereafter, Asadi \& Mehri [19] detected no difference between patients received NTG/LA combination or LA alone in hemodynamic parameters before tourniquet inflation, at any time after inflation and after its deflation.

\section{Conclusion}

The use of IVRA for hand and distal forearm surgery is efficient and safe modality for IO anesthesia and PO analgesia. Addition of NTG to LA improved anesthetic outcome and allowed shortening of initiation of surgery, less IO and PO analgesic consumption. Reduction of LA dose did not compromise the reported improved anesthetic outcome. Rapid tourniquet release did not alter patients hemodynamic.

\section{References}

1. Song L, Wu C, Liu J, Zuo Y, Volinn E, et al. (2015) Potential advantages of an additional forearm rubber tourniquet in intravenous regional anesthesia: a randomized clinical trial. J Anesth 29(4): 551-556.

2. Hadzic A, Arliss J, Kerimoglu B, Karaca PE, Yufa M, et al. (2004) A comparison of infraclavicular nerve block versus general anesthesia for hand and wrist day-case surgeries. Anesthesiology 101(1): 127-132.

3. Glynn A, Strunk S, Reidy D, Hynes DE (2005) Carpal tunnel release using local anaesthetic and a forearm tourniquet. Ir Med J 98(5): 144145.

4. Singh R, Bhagwat A, Bhadoria P, Kohli A (2010) Forearm IVRA, using $0.5 \%$ lidocaine in a dose of $1.5 \mathrm{mg} / \mathrm{kg}$ with ketorolac $0.15 \mathrm{mg} / \mathrm{kg}$ for hand and wrist surgeries. Minerva Anestesiol 76(2): 109-114

5. Verma RN, Hasnain S, Sreevastava DK, Murthy TV (2016) Anaesthetic management of forearm fractures using a combination of haematoma block and intravenous regional anaesthesia. Med J Armed Forces India 72(3): 247-252.

6. Al Metwalli RR (2009) Evaluation of the tourniquet leak during forearm intravenous regional anesthesia -- manual vs automatic pump injection. Middle East J Anaesthesiol 20(2): 271-276.

7. Lees DA, Penny JB, Baker P (2016) A single blind randomised controlled trial of the impact on patient-reported pain of arm elevation versus exsanguination prior to tourniquet inflation. Bone Joint J 98-B(4): 519525.
8. Bilku DK, Downing ND (2009) Simple technique for exsanguination of the hand. Surgeon 7(6): 379-380.

9. Den Uil CA, Brugts JJ (2015) Impact of intravenous nitroglycerin in the management of acute decompensated heart failure. Curr Heart Fail Rep 12(1): 87-93

10. Boden WE, Padala SK, Cabral KP, Buschmann IR, Sidhu MS (2015) Role of short-acting nitroglycerin in the management of ischemic heart disease. Drug Des Devel Ther 9: 4793-4805.

11. Berrazueta JR, Salas E, Ochoteco A, Poveda JJ, Sánchez de Vega MJ (1993) The peripheral analgesic action of the exogenous nitric oxidedonor: nitroglycerin. A placebo-controlled study of the transdermal action of nitroglycerin on pain sensitivity in the forearm. Rev Esp Cardiol 46(1): 10-14.

12. Amarante LH, Duarte ID (2002) The kappa-opioid agonist (+/-)-bremazocine elicits peripheral antinociception by activation of the L-arginine/nitric oxide/cyclic GMP pathway. Eur J Pharmacol 454(1): 19-23.

13. Lim E, Shukla L, Barker A, Trotter DJ (2015) Randomized blinded control trial into tourniquet tolerance in awake volunteers. ANZ J Surg 85(9): 636-638.

14. Jafarian A, Hassani V, Jesmi F, Ramezani K, Javaheri F, et al. (2015) Efficacy of a Modified Bier's Block in Patients Undergoing Upper Limb Bone Surgery. Anesth Pain Med 5(1): e22007.

15. Badeaux J, Bonanno L, Au H (2015) Effectiveness of ondansetron as an adjunct to lidocaine intravenous regional anesthesia on tourniquet pain and postoperative pain in patients undergoing elective hand surgery: a systematic review protocol. JBI Database System Rev Implement Rep 13(1): 27-38.

16. Wilson JK, Lyon GD (1989) Bier block tourniquet pressure. Anesth Analg 68(6): 823-824

17. Kraemer HC, Theimann S (1987) How many subjects? Statistical power analysis in research. Behavior Research Methods, Instruments, \& Computers 22(5): 486

18. Murphy KR, Myors B (2004) Statistical Power Analysis: A Simple and General Model for Traditional and Modern Hypothesis Tests. $2^{\text {nd }}$ Edn.

19. Asadi HK, Mehri D (2013) The analgesic effect of nitroglycerin added to lidocaine on quality of intravenous regional anesthesia in patients undergoing elective forearm and hand surgery. Acta Cir Bras 28(1): 1925.

20. Cakmak BM, Cakmak G, Akpek E, Arslan G, Sahin MS (2014) Peri- and postanalgesic properties of lidokain, lornoxicam, and nitroglycerine combination at intravenous regional anesthesia. Biomed Res Int 2014:737109.

21. Bansal P, Baduni N, Bhalla J, Mahawar B (2015) A comparative evaluation of magnesium sulphate and nitroglycerine as potential adjuncts to lidocaine in intravenous regional anaesthesia. Int J Crit Illn Inj Sci 5(1): 27-31.

22. Hashimoto S, Kobayashi A (2003) Clinical pharmacokinetics and pharmacodynamics of glyceryl trinitrate and its metabolites. Clin Pharmacokinet 42(3): 205-221.

23. Lauretti GR, Perez MV, Reis MP, Pereira NL (2002) Double-blind evaluation of transdermal nitroglycerine as adjuvant to oral morphine for cancer pain management. J Clin Anesth 14(2): 83-86.

24. Lin Q Peng YB, Wu J, Willis WD (1997) Involvement of cGMP in nociceptive processing by and sensitization of spinothalamic neurons in primates. J Neurosci 17(9): 3293-3302.

25. Toda N, Kishioka S, Hatano Y, Toda H (2009) Modulation of opioid actions by nitric oxide signaling. Anesthesiology 110(1): 166-181. 
26. Bogdanov MB, Wurtman RJ (1997) Possible involvement of nitric oxide in NMDA-induced glutamate release in the rat striatum: an in vivo microdialysis study. Neurosci Lett 221(2-3): 197-201.

27. Fukami S, Uchida I, Mashimo T, Takenoshita M, Yoshiya I (1998) Gam ma subunit dependent modulation by nitric oxide (NO) in recombinant GABAA receptor. Neuroreport 9(6): 1089-1092.
28. Honarmand A, Safavi M, Fatemy A (2011) The analgesic effect of three different doses of nitroglycerine when added to lidocaine for intravenous regional anesthesia in trauma patients. Ulus Travma Acil Cerrahi Derg 17(6): 497-503.

Your next submission with Juniper Publishers will reach you the below assets

- Quality Editorial service

- Swift Peer Review

- Reprints availability

- E-prints Service

- Manuscript Podcast for convenient understanding

- Global attainment for your research

- Manuscript accessibility in different formats

( Pdf, E-pub, Full Text, Audio)

- Unceasing customer service

Track the below URL for one-step submission https://juniperpublishers.com/online-submission.php 